\title{
Does Knitted Shade Provide Temperature Reduction and Increase Yield Kale?
}

\author{
Santino Seabra Júnior ${ }^{1}$, Franciely da Silva Ponce ${ }^{1}$, Claudia Aparecida de Lima Toledo ${ }^{1}$, \\ Márcio Roggia Zanuzzo ${ }^{2}$, Rivanildo Dallacort ${ }^{3} \&$ Giuseppina Pace Pereira Lima ${ }^{4}$ \\ ${ }^{1}$ Departamento de Agronomia, Universidade do Estado de Mato Grosso, Nova Mutum, Mato Grosso, Brazil \\ ${ }^{2}$ Departamento de Agronomia, Universidade Federal de Mato Grosso, Sinop, Mato Grosso, Brazil \\ ${ }^{3}$ Departamento de Agronomia, Universidade do Estado de Mato Grosso, Tangará da Serra, Mato Grosso, Brazil \\ ${ }^{4}$ Institute of Bioscience, Department of Chemistry and Biochemistry, São Paulo State University, Botucatu, São \\ Paulo, Brazil \\ Correspondences: Giuseppina Pace Pereira Lima, Institute of Bioscience, Department of Chemistry and \\ Biochemistry, São Paulo State University, Botucatu, CEP 18618-000, São Paulo, Brazil. Tel: 55-149-9143-4868. \\ E-mail: finalima@gmail.com \\ Santino Seabra Junior, Department of Agronomy, Universidade do Estado do Mato Grosso, Nova Mutum, CEP \\ 78450-000, Mato Grosso, Brazil. E-mail: santinoseabra@hotmail.com
}

$\begin{array}{lc}\text { Received: March 13, } 2019 & \text { Accepted: April 25, } 2019 \quad \text { Online Published: June 30, } 2019 \\ \text { doi:10.5539/jas.v11n9p103 } & \text { URL: https://doi.org/10.5539/jas.v11n9p103 }\end{array}$

The research is financed by Conselho Nacional de Desenvolvimento Cientifico e Tecnológico (CNPq), grant 305177/2015-0 and Fundação de Amparo à Pesquisa de Mato Grosso, grant 224287/2015.

\begin{abstract}
We aimed to evaluate whether the air temperature, soil temperature, and luminosity in a low tunnel covered with agricultural mesh screening affected the characteristics of kale production. The study was conducted on the cultivation of kale in six different growing environments. The experimental setup consisted of randomized block design $(\mathrm{RBD})$ with factorial analysis $(2 \times 6)$ with four repetitions. The kale (Brassica oleracea $\mathrm{L}$. var. acephala) hybrids Hi Crop and Kobe F1 were used as plant material. The growing environments were open field and protected environments consisting of low tunnels, each covered with a different mesh screen: red, thermo-reflective silver, black, tissue-non-tissue (TNT), and organza fabric. Sensors were installed within each environment to monitor air temperature and soil temperature. The TNT screen resulted in the highest air and soil temperatures and lower yield. The black mesh resulted in lower temperatures than other coverings. Organza fabric provided the best yield (22.8\%) compared to open field and it was 9.89 to $42.19 \%$ more productive compared to the other meshes. Organza fabric was the best environment for the cultivation of kale in tropical climates. These data confirm that kale biomass production was greatly affected by stress high temperature.
\end{abstract}

Keywords: Brassica oleracea L., organza fabric, protected cultivation, tropical horticulture

\section{Introduction}

The brassicas are vegetables that present a good nutritional potential and high contents of bioactive compounds (Borges, Seabra Júnior, Ponce, \& Lima, 2018). Kale, cabbage, cauliflower and broccoli are the most consumed ones and, nowadays, occupy 3.816,58 hectares of cultivated area, with production of 96.492,922 tons (FAO-FAOSTAT, 2018). The kale (Brassica oleracea L. var. acephala) is a specie adapted to temperate climate and temperatures above $32{ }^{\circ} \mathrm{C}$ affect the plant's biomass accumulation and compromises the leaf expansion (Maynard \& Hochmuth, 2007, Rodriguez et al., 2015). High temperatures also affect the carbon assimilation rate, oxygen production, transport of electrons and photophosphorylation (Allakhverdiev et al., 2008), affecting the photosynthesis, with consequent modifications in the productivity, besides inducing heat stress. High levels of radiation can also promote oxidative stress, likewise affecting the photosynthetic apparatus, inducing an imbalance between energy supply and energy consumption, leading to photoinhibition (Dat et al., 2000). 
The use of a protected environment becomes an efficient alternative for vegetable production in unfavorable climates by creating a microclimate in which it is possible to control environmental conditions, such as temperature, humidity, and radiation (Romanini, Garcia, Alvorado, Cappelli, \& Umezu, 2010). Changing the internal climate of different types of protected environments depends on the type of environment and the type coverage used. A great variety of materials are available commercially for use in creating protected environments, such as shading mesh, thermo-reflective meshes, and tissue-non-tissue (TNT). Additionally, it is possible to use organza fabric for the same purpose.

Among the protected environments used in the cultivation of vegetables, the low tunnel type is considered the least expensive and easiest to implement (Figueiredo, Malheiros, \& Braz, 2002). In recent years, because of fears surrounding climate change, several alternatives of agricultural shade screens have been studied to reduce crop exposure to radiation and ultraviolet radiation (UV) light and, consequently, control soil and air temperature. Such shading can be used for the cultivation of primarily vegetables in seasons of high energy availability. Decreasing solar radiation is important because it has an effect on energy balance in terms of the fluctuation between sensible and latent heat in addition to the photosynthetic process (Pezzopane, Oliveira, Reis, \& Lima, 2004).

In comparison to open field cultivation, mesh shading provides a decrease in the minimum, medium, and maximum values of luminosity and temperature as well as an increase in relative humidity (Rampazzo, Seabra Júnior, Nunes, \& Neves, 2014). The manipulation of temperature that occurs within tunnels is important for reducing plants' physiological stress via biochemical pathways and reducing postharvest physiological disturbance. A plant under thermal stress shows impaired development as well as, in severe cases, programmed senescence (Szabados Kováscs, Zilberstein, \& Bouchereau, 2011). In particular, an excess of rainfall, high temperatures, and insect infestation affects the production of brassicas in tropical climates.

To decrease such climatic effects, it is necessary to adopt or create technologies that enable the cultivation of these species by combining tolerant cultivars with protected cultivation for the purpose of maximizing photosynthetic potential with maximum yield and postharvest quality. However, the response of the plants depends on the adaptability of the coverage material, requiring monitoring of the climatic variables inside the cultivation environment.

Therefore, we aimed to evaluate the climate conditions (air temperature, soil temperature, and luminosity) in low tunnels covered with mesh screening and the screens' effects on the characteristics of kale productivity.

\section{Materials and Methods}

This study was carried out at Mato Grosso State University (UNEMAT)-Nova Mutum, Brazil-latitude $13^{\circ} 49^{\prime} 44^{\prime \prime}$ $\mathrm{S}$, longitude $56^{\circ} 04^{\prime} 56^{\prime \prime} \mathrm{W}$, and altitude $460 \mathrm{~m}$. The Köppen climate classification of the area is tropical (Aw), with an average annual rainfall of $1,900 \mathrm{~mm}$ and high average temperature-average of $24{ }^{\circ} \mathrm{C}$ and average maximum at $34{ }^{\circ} \mathrm{C}$ (Nogueira et al., 2010). The soil is characterized as dystrophic red-yellow latosol (EMBRAPA, 2013).

The randomized block design (RDB) experimental setup was used along with factorial analysis $(2 \times 6$; two cultivars $\times$ six ambiance treatments) with four replicates on the experimental fields. Each experimental plot had 15 plants, and we collected six central plants. Kale (Brassica oleracea L. var. acephala) hybrids Hi Crop (Takii, Brazil) and Kobe F1 (TopSeed) were used as plant material. Six different ambiance treatments were used in low tunnels: TNT $\left(15 \mathrm{~g} \mathrm{~m}^{-2}\right)$, white polyester organza mesh (organza fabric) $\left(47 \mathrm{~g} \mathrm{~m}^{-2}\right)$, red mesh (Chromatinet ${ }^{\circledR} 35 \%$ ), silver (Aluminet ${ }^{\mathbb{B}} 50 \%$ ), and black mesh (Sombrite ${ }^{\mathbb{B}} 35 \%$ ). Open field cultivation was used as the control. All of the tunnels were $1 \mathrm{~m}$ high, $8 \mathrm{~m}$ long, and $1.2 \mathrm{~m}$ wide.

The seeds were sown in plastic pots $(250 \mathrm{~mL})$ filled with the commercial substrate VIVATO ${ }^{\circledR}$ and using one seed per pot. The seedlings were kept in a seedling nursery and transplanted to the field 46 days after seeding. The transplant was performed in paired-rows with distances of $0.4 \mathrm{~m}$ and $1.2 \mathrm{~m}$ between two rows in a pair and between two consecutive paired-rows, respectively, and plant-to-plant spacing was $0.5 \mathrm{~m}$, which corresponds to a population of 23,400 plants ha ${ }^{-1}$.

The fertilization was performed with 400 kilograms $(\mathrm{kg}) \mathrm{ha}^{-1}$ of $\mathrm{P}_{2} \mathrm{O}_{5}, 160 \mathrm{~kg} \mathrm{ha}^{-1}$ of $\mathrm{K}_{2} \mathrm{O}$, and $40 \mathrm{kgha}^{-1}$ of N, using simple superphosphate, potassium chloride, and urea as the source, in addition to $40 \mathrm{tha}^{-1}$ of poultry manure. Topdressing fertilization was performed by fertigation with $40 \mathrm{~kg} \mathrm{ha}^{-1}$ of $\mathrm{N}$ and $20 \mathrm{~kg} \mathrm{ha}^{-1}$ of $\mathrm{K}_{2} \mathrm{O}$ over five days, using ammonium sulphate and potassium nitrate as the source of nitrogen and potassium (Trani et al., 1997). Irrigation was performed with a drip irrigation system with of $172.2 \mathrm{~mm}$. Leaf fertilization was performed every 15 days using $1 \%$ ammonium molybdate and $1 \%$ boric acid. 
Two type K thermocouples (Chromel $+{ }^{\circledR}$, Alumel- ${ }^{\circledR}$ ) were installed in each environment and connected to a data logger system for data acquisition (Campbell Scientific, data logger model CR1000) to record the air and soil temperatures. To analyse the soil temperature, the thermocouples were placed at a depth of $0.10 \mathrm{~m}$ in the center of each parcel. To analyse the air temperature, one thermocouple was placed at a height of $0.30 \mathrm{~m}$. The data logger was programmed to record readings every second, to store the arithmetic means at one-hour intervals, and to calculate hourly averages. Meteorological data regarding rainfall and air temperature were obtained from one of Campbell Scientific's automated weather stations, equipped with a pluviometer (model CS700), located $10 \mathrm{~m}$ from the experiment area.

The experiment's period of execution was 30 days, from the transplant period to the beginning of the harvest. Destructive testing was used on six plants in each plot. The temperature air and soil inside the tunnels were registered each hour, and the graph represents each six hours expressing thermal variations among the environments. The luminous incidence (LUX) inside each environment was obtained with a luximeter model 540 Testo $^{\circledR}$, and the daily measurements were taken at 2:00 pm.

The evaluations were regarding agronomic variables: plant height $(\mathrm{cm})$, plant diameter $(\mathrm{mm})$, total plant weight $\left(\mathrm{g}\right.$ plant $\left.{ }^{-1}\right)$, commercial weight of leaves (unit plant $\left.{ }^{-1}\right)$, and commercial yield $\left(\mathrm{t} \mathrm{ha}^{-1}\right)$.

\subsection{Statistical Analysis}

The data analysis was performed via variance analysis and means were compared via Tukey's test $(\mathrm{p} \leq 0.05)$ using the Assistat software version 7.7 beta (PT) (Silva \& Azevedo, 2016).

\section{Results and Discussion}

The highest registered temperature occurred in the low tunnel covered with TNT, which reached the maximum temperature (average $=41.4^{\circ} \mathrm{C}$ ) at 2:00 pm (Figure 1). The same temperature was also observed in the organza tunnel, which showed the highest productivity $\left(6.47 \mathrm{t} \mathrm{ha}^{-1}\right)($ Table 1$)$. The lowest temperatures were verified in the tunnels covered with silver mesh $\left(35.1^{\circ} \mathrm{C}\right)$ and black mesh $\left(35^{\circ} \mathrm{C}\right)$ (Figure 1), with a difference of $6.2{ }^{\circ} \mathrm{C}$ between TNT and the black mesh. The ideal temperature for kale is $15.5-18.3{ }^{\circ} \mathrm{C}$ (Maynard \& Hochmuth, 2007) and the average and maximum temperatures registered were $25.6{ }^{\circ} \mathrm{C}$ and $33.5{ }^{\circ} \mathrm{C}$, respectively, which is unfavorable for good kale production. High temperatures compromise the leaf expansion, reduce the leaf size and the weight of the aerial part of the plant, mainly when the plants are cultivated under temperatures above $32{ }^{\circ} \mathrm{C}$ (Rodriguez et al., 2015).

The air temperature began to increase at 7:00 am in all the environments, and the highest temperatures were verified in the organza and TNT tunnels until 1:00 pm. A higher daily air temperature average in environments covered with TNT was also verified by Pires, Santos, Santos, Vasconcelos \& Aragão (2013), i.e., this material provides higher temperatures in the hotter hours of the day $\left(47^{\circ} \mathrm{C}\right)$ compared to open-field cultivation $\left(36.5^{\circ} \mathrm{C}\right)$. In our study, the TNT induced the highest temperature, and in response, kale showed a low yield $\left(4.56 \mathrm{t} \mathrm{ha}^{-1}\right)$, similar to what was found in open field $\left(4.53 \mathrm{t} \mathrm{ha}^{-1}\right)$. Both treatments presented a lower yield than organza $(6.47 \mathrm{t}$ $\mathrm{ha}^{-1}$ ). Other vegetable have different results. Lettuce cultivated in high-temperature conditions and in TNT-protected environment, showed a higher productivity, with variations between 20 to $120 \%$, depending on the used genotype, (cvs. Tainá, Baba de Verão and Veronica) (Oliveira, Grangeiro, B. S. Souza, \& S. R. R. Souza, 2006). Other study with lettuce cultivated under TNT showed the greater productivity, height, and diameter of head than cultivated in open field (Barros Júnior et al., 2004). 

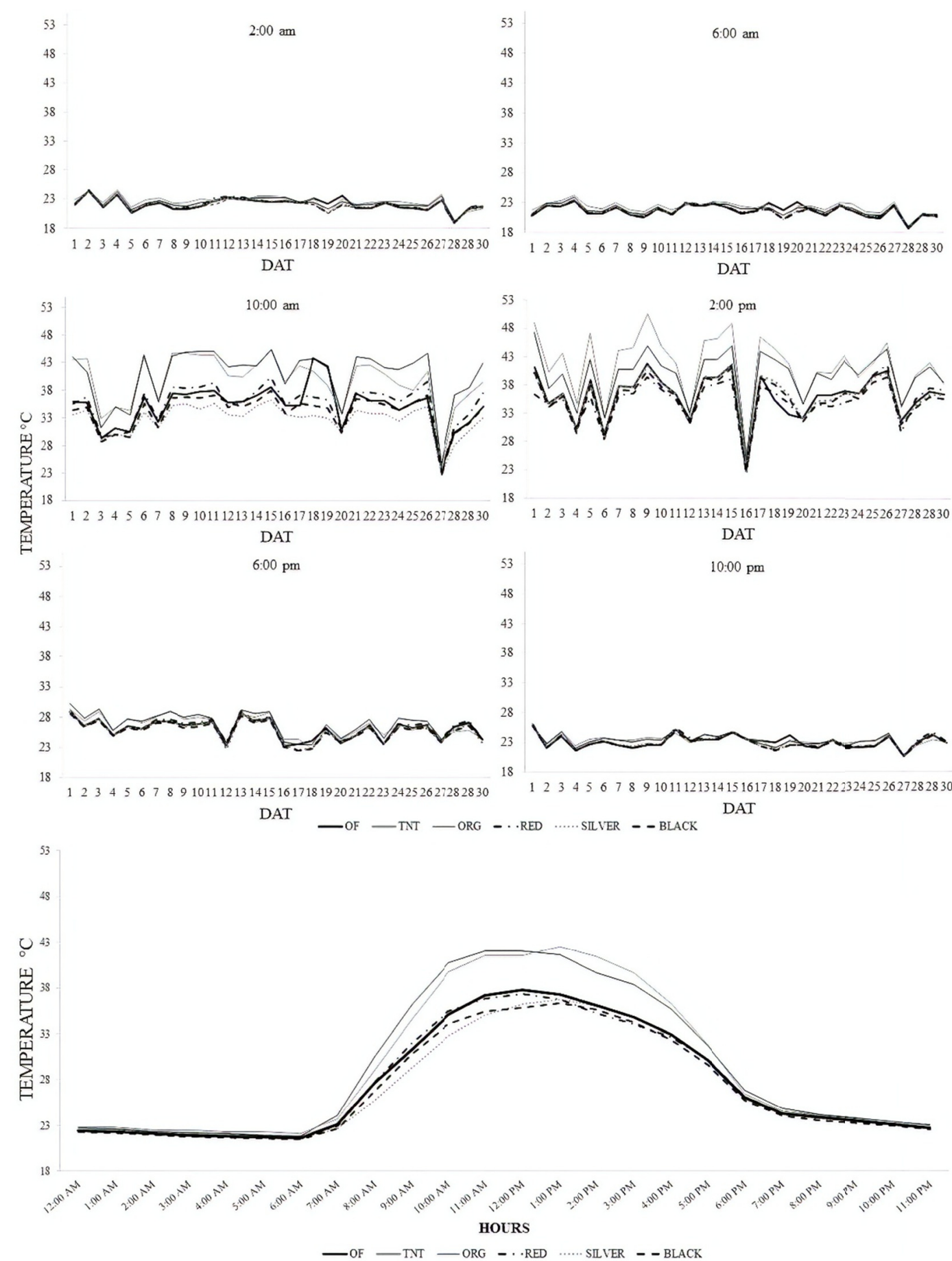

Figure 1. Average air temperatures registered at 2:00 am, 6:00 am, 10:00 am, 2:00 pm, 6:00 pm, and 10:00 pm, in days after transplanting (DAT) of kale and average air temperatures in function of the daily hours in the open field (OF), TNT, organza (ORG), red mesh (RED), silver mesh (SILVER), and black mesh

(BLACK) environments

In organza fabric low tunnels the air temperatures was closer to those registered in the environment covered with TNT, but there are no reports about of this material for agricultural purposes. However, the synthetic composition of fabric ( $100 \%$ polyamide) could have contributed to increasing the air temperature inside the cultivation environment. High temperatures affect the opening and closing of stomata, altering the photosynthetic and photorespiration rates, and, consequently, the yield (Bisbis, Gruda, \& Blanke, 2018). Moderately high temperatures cause direct damages to the photosynthetic apparatus, e.g., when the temperature 
is higher than $40{ }^{\circ} \mathrm{C}$, the photosystem II (PS II) is affected and the photosynthesis might be limited by mechanisms as the alteration of the Rubisco activity (ribulose-1,5-bisphos-phate carboxylase/oxygenase), regeneration rate of RuBP (ribulose 1,5-bisphosphate) or the usage rate of triosephosphate (Wise, Olson, Schrader, \& Sharkey, 2004). The use of a protected environment has the function of providing a microclimate that favors the plants' development. Thus, there is an increase in productivity and providing the cultivation in unfavorable periods or even for protection against climate hazards such as hail, frost, rain, and high temperatures. In addition, the protected environment can be used with the aim of decreasing the infestation of insects-pests, acting as a physical barrier. Besides the microclimatic variations that occur inside the protected environment, it is necessary to evaluate the plants' productive responses, since the aim of this technology is to obtain high productivity.

Red mesh was used in kale cultivation to reduce the luminous intensity and, consequently, the temperature in tropical climates (Li, 2006). Inside of the red mesh tunnel, we did not verify a temperature reduction (Figure 2). During the hottest time of the day $(2: 00 \mathrm{pm})$, the tunnel covered with red mesh maintained the highest temperatures, along with the tunnel covered with black mesh. According to Li (2006), the red mesh affects the quality of radiation that is transmitted to the environment's interior. Its effect reduces the quantity of waves of the blue, green, and yellow spectrum bands while increasing the quantity of red and far-red waves, which are thermal waves, thus increasing the air temperature. The silver and black mesh were efficient at reducing the air temperature (Figure 1), although this is not reflected in the yield and may not occur in other species.

Lettuce cultivated in tropical regions with silver, black and red mesh showed a net increase in the number of leaves and the leaf area index, and this effect was attributed to the lower temperature promoted by the three mesh (Sales, Barbosa Filho, Barbosa, Viana, \& Freitas, 2014). The authors also verified a respective decrease of $4.7{ }^{\circ} \mathrm{C}$ and $3.6{ }^{\circ} \mathrm{C}$ in the average temperatures inside the environments when compared to the control environment (covered with transparent plastic), providing results that match those found in the present study. In environments covered with thermo-reflective meshes (silver), this effect is due to the reflection of infrared radiation (Costa, Santos, \& Vieira, 2011), explaining the results obtained in the present study i.e., the silver mesh kale cultivation showed a high yield (5.83 $\left.\mathrm{tha}^{-1}\right)$ (Table 1).

Shading meshes induced a decrease in the incident radiation. Thus, they provided a decrease in the cultivation environment's temperature. In environments covered with thermo-reflective meshes, this effect is due to the reflection of infrared radiation (Costa, Santos, \& Vieira, 2011), explaining the results obtained in our study.

Regarding the soil temperature, we observed that at 2:00 pm, there were higher temperatures recorded in the environments covered with TNT, organza, and red mesh (Figure 2). This effect resulted in a higher maintenance of the soil temperature in comparison to the other coverings that provided temperatures $1{ }^{\circ} \mathrm{C}$ lower on average. There were no great variations in the soil temperature variation, during the $24 \mathrm{~h}$, although there was a steep increase beginning at 9:00 am that reached a maximum value at 2:00 pm $\left(28^{\circ} \mathrm{C}\right)$ in the open field and in TNT (Figure 2). During the day, the highest average soil temperatures were observed in the environment covered with TNT (Figure 2). We also observed that the soil temperatures registered between 6:00 pm and 7:00 am were higher than the air temperatures registered inside the environments. This happens due to the low capacity of the soil in the heat exchange (heat retention), since the heat flux in the interior of the soil is slower than that in the air (Geiger, 1980). The lowest average soil temperatures were registered in the black mesh environment, with a low amplitude during the day $\left(28.7^{\circ} \mathrm{C}\right.$ maximum and $25^{\circ} \mathrm{C}$ minimum) (Figure 2). In the same way, in the red mesh, the average soil temperatures were similar to the ones observed in the black mesh (2:00 pm); however, the energy absorbed in the form of heat inside this environment tends to dissipate with more difficulty. In the period between 6:00 pm and 7:00 am, we observed that the soil temperature inside the red mesh tunnel was similar to that in the TNT tunnel and was $1.3^{\circ} \mathrm{C}$ higher that in the other environments. The values registered for the tunnel covered with organza were the same as the values verified in the open field, with an average difference of $1.3{ }^{\circ} \mathrm{C}$. The tunnel covered with black mesh produced the lowest soil temperatures, followed by the environments covered with silver mesh $\left(26.4{ }^{\circ} \mathrm{C}\right)$ and red mesh $\left(26.8^{\circ} \mathrm{C}\right)$.

Even though the organza and TNT produced a rise in air temperatures (7:00 am to 2:00 pm), only the TNT tunnel showed the highest soil temperatures (Figure 2). A study by Rampazzo, Seabra Júnior, Nunes, and Neves (2014) shows that environments covered with 40 and $50 \%$ thermo reflective mesh induced the higher efficiency in the reduction of air and soil temperatures, as well as, in luminosity, compared to the open field. 

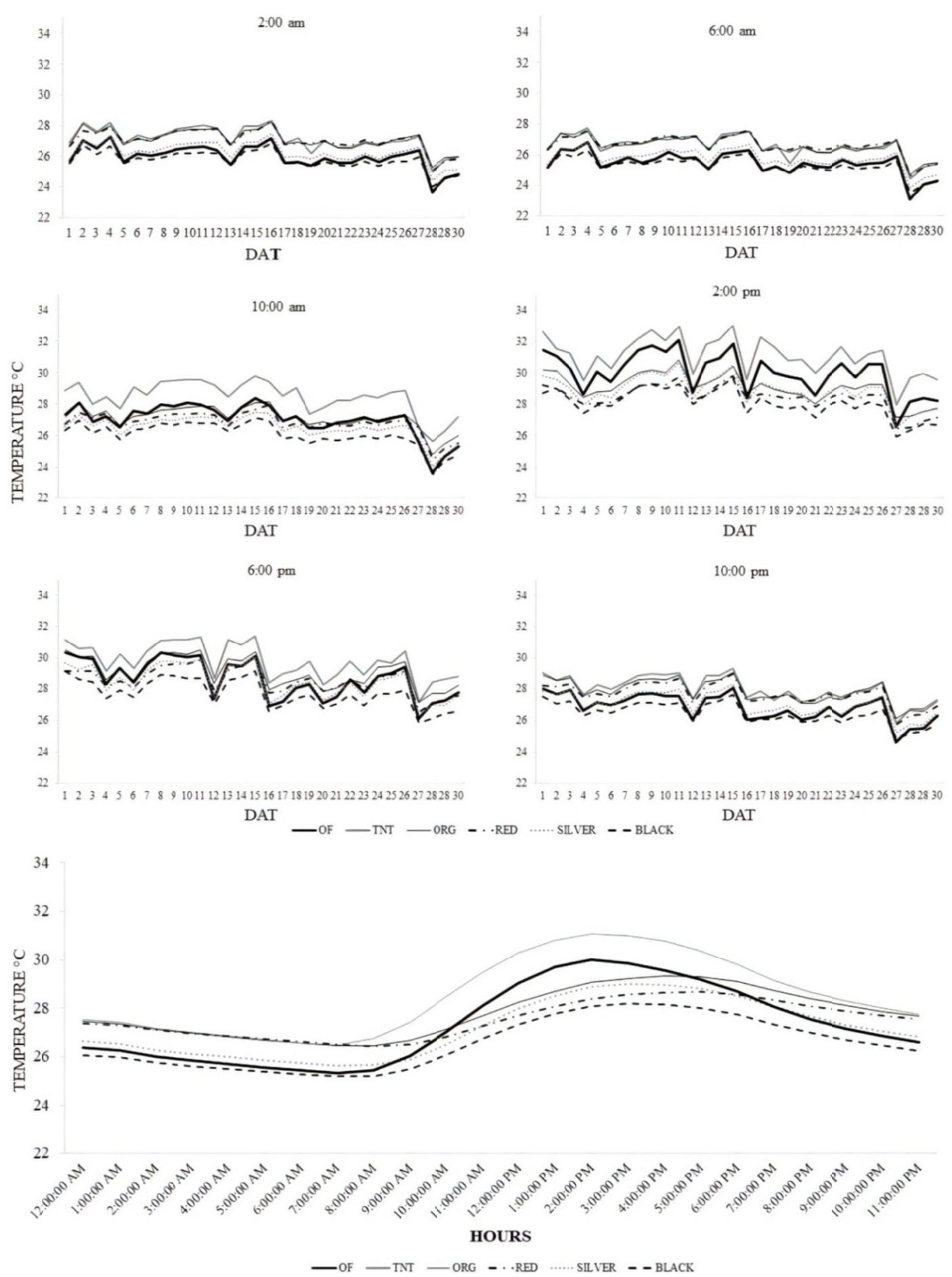

Figure 2. Average daily soil temperatures at 2:00 am, 6:00 am, 10:00 am, 2:00 pm, 6:00 pm and 10:00 pm, in days after transplanting (DAT) of kale and average air temperatures in function of the daily hours in the environments of the open field (OF), TNT, organza (ORG), red mesh (RED), silver mesh (SILVER) and black mesh (BLACK)

There was no statistical difference for any of the evaluated agronomic variables (plant height, diameter, total weight, commercial weight and commercial productivity) in relation to the kale hybrids (Table 1). The lowest values of plant height were observed in kale produced in the open field, while the higher plants were verified in kale cultivated in the black and silver mesh tunnels. Kale cultivated in black mesh showed higher diameters and, when cultivated in red mesh, produced the lowest fresh weight. 
Table 1. Plant height, diameter, number of leaves, total fresh and commercial weight and productivity of kale plants cultivated under low tunnels covered with different meshes as well as in an open field

\begin{tabular}{|c|c|c|c|c|c|}
\hline Treatments & $\begin{array}{l}\text { Plant height } \\
(\mathrm{cm})\end{array}$ & $\begin{array}{l}\text { Plant diameter } \\
(\mathrm{cm})\end{array}$ & $\begin{array}{l}\text { Total fresh weight } \\
\left(\mathrm{g} \text { plant }^{-1}\right)\end{array}$ & $\begin{array}{l}\text { Commercial fresh weight } \\
\left(\mathrm{g} \mathrm{plant}^{-1}\right)\end{array}$ & $\begin{array}{l}\text { Yield } \\
\left(\mathrm{t} \mathrm{ha}^{-1}\right)\end{array}$ \\
\hline \multicolumn{6}{|l|}{ Hybrids } \\
\hline Hi-crop & $47.09 \mathrm{a}$ & $37.78 \mathrm{a}$ & $324.00 \mathrm{a}$ & $213.32 \mathrm{a}$ & $4.99 \mathrm{a}$ \\
\hline Kobe & $46.48 \mathrm{a}$ & $38.53 \mathrm{a}$ & $317.14 \mathrm{a}$ & $222.07 \mathrm{a}$ & $5.2 \mathrm{a}$ \\
\hline SMD & 1.38 & 2.18 & 39.40 & 30.25 & 30.25 \\
\hline \multicolumn{6}{|l|}{ Environments } \\
\hline Open field & $42.56 \mathrm{c}$ & $35.60 \mathrm{~b}$ & $298.54 \mathrm{ab}$ & $193.70 \mathrm{bc}$ & $4.53 \mathrm{bc}$ \\
\hline TNT & $46.67 \mathrm{ab}$ & $36.08 \mathrm{ab}$ & $317.29 \mathrm{ab}$ & $194.96 \mathrm{bc}$ & $4.56 \mathrm{bc}$ \\
\hline Organza & $47.67 \mathrm{ab}$ & $40.25 \mathrm{ab}$ & $377.41 \mathrm{a}$ & $276.46 \mathrm{a}$ & $6.47 \mathrm{a}$ \\
\hline Redmesh & $44.79 \mathrm{bc}$ & $34.92 \mathrm{~b}$ & $223.92 \mathrm{~b}$ & $159.81 \mathrm{c}$ & $3.74 \mathrm{c}$ \\
\hline Silver mesh & $48.90 \mathrm{a}$ & $40.49 \mathrm{ab}$ & $348.46 \mathrm{a}$ & $249.37 \mathrm{ab}$ & $5.83 \mathrm{ab}$ \\
\hline Black mesh & $50.12 \mathrm{a}$ & $41.58 \mathrm{a}$ & $357.79 \mathrm{a}$ & $231.87 \mathrm{abc}$ & $5.42 \mathrm{abc}$ \\
\hline SMD & 3.55 & 5.60 & 101.12 & 77.65 & 77.65 \\
\hline
\end{tabular}

Note. Means followed by the same letter in the column do not differ by Tukey test $(\mathrm{p}<0.05)$. SMD-standardized mean difference.

The best results for commercial fresh weight (leaves) were observed in kale cultivated in the organza tunnel, due to less damage caused by insects and a greater weight in relation to the other growing environments. However, it was also possible to determine that kale cultivated under organza, even though it did not produce better results for plant height, diameter or number of leaves, provided stronger plants with a higher total weight, a higher commercial weight of leaves and higher yield $\left(6.47 \mathrm{t} \mathrm{ha}^{-1}\right)$. These results were equally favorable for the cultivation of this vegetable.

Among the evaluated screens, the low tunnel covered with TNT produced a higher luminosity (49,898 Lux), with a reducing of $27.6 \%$ (Figure 3 ) in relation to open field. The handling of luminosity inside the cultivation environment is important, since the materials used in the protection of this environment have blockage rates of variable luminosity. A reduction of $44.4 \%, 50.3 \%$ and $46.4 \%$ in luminous incidence was observed in the environments covered with red, silver and black mesh, respectively, in relation to the open field. As expected, the open field produced a higher luminosity (68,839 Lux) (Figure 3) and a lower yield. Moreover, kale cultivated under organza showed the higher yield, although this screen has not been the most efficient in reducing luminosity (33.8\% of reduction). Solar radiation is one of the main components of the energetic balance and of the plants' development. The light is essential for growth, providing energy for photosynthesis as well as regulating development through light receptors sensitive to different intensities.

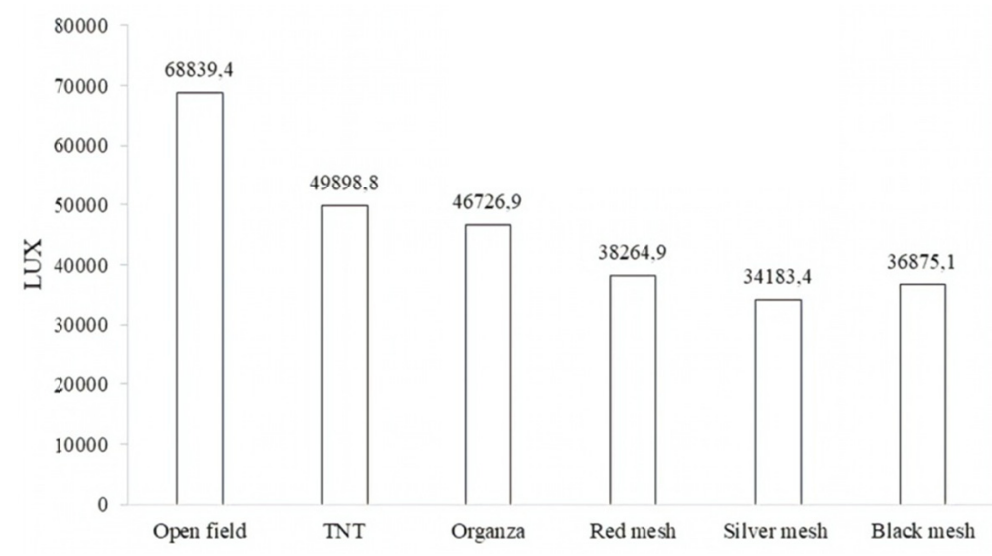

Figure 3. Average luminosity in Lux registered in the environments: open field, TNT, organza, red mesh, silver thermo reflective mesh and black shading mesh, measured at 2:00 pm during the evaluation period 
The visible fraction of solar energy contains active photosynthetic irradiance and is one of the most important factors in determining the plants' productivity (Bergin, Ghoroi, Dixit, Schauer, \& Shindell, 2017). The luminosity control directly influences the photosynthetic process, exerting positive or negative effects. This study is important in determining the physiological needs of each species when choosing the material to be employed. In tropical conditions, extreme luminosity peaks are easily reached. In environments with intense solar radiation and high temperatures, the plants avoid excess heating of the leaves, reducing the absorption of this radiation (Ferrante \& Mariani, 2018). Thus, photosynthesis and, consequently, the plants' development are also compromised. Both an excess of and an insufficient amount of light influence the plants' development. With low tunnel covered with agricultural mesh is necessary to check the luminosity, as well as air and soil temperature inside protected environments to improve the yield and quality of plant production. Each material will be dependent on the breeding status and climatic adaptation.

Cultivation in TNT is inappropriate due to the highest air and soil temperatures in this environment. On the other hand, the use of black mesh produced a reduction in air and soil temperature. Even though the results in these two cases are opposite, neither mesh type is recommended, because of the low kale productivity. Kale cultivation under organza showed the best yield, demonstrating that this material can be an innovation for the kale cultivation in regions with high temperatures.

\section{References}

Allakhverdiev, S. I., Kreslavski, V. D., Klimov, V. V., Los, D. A., Carpentier, R., \& Mohanty, P. (2008). Heat stress: An overview of molecular responses in photosynthesis. Photosynthesis Research, 98(1-3), 541-550. https://doi.org/10.1007/s11120-008-9331-0

Barros Júnior, A. P., Grangeiro, L. C., Bezerra Neto, F., Negreiros, M. Z., Souza, J. O., Azevedo, P. E., \& Medeiros, D. C.(2004). Cultivo da alface em túneis baixos de agrotêxtil. Horticultura Brasileira, 22(4), 801-803. https://doi.org/10.1590/S0102-05362004000400028

Bergin, M. H., Ghoroi, C., Dixit, D., Schauer, J. J., \& Shindell, D. T. (2017). Large Reductions in Solar Energy Production Due to Dust and Particulate Air Pollution. Environmental Science and Technology Letters, 4(8), 339-344. https://doi.org/10.1021/acs.estlett.7b00197

Bisbis, M. B., Gruda, N., \& Blanke, M. (2018). Potential impacts of climate change on vegetable production and product quality-A review. Journal of Cleaner Production, 170, 1602-1620. https://doi.org/10.1016/ j.jclepro.2017.09.224

Borges, C. V., Seabra Júnior, S., Ponce, F. S., \& Lima, G. P. P. (2016). Agronomic Factors Influencing Brassica Productivity and Phytochemical Quality. Brassica Germplasm Characterization, Breeding and Utilization (pp. 57-74). https://doi.org/10.5772/intechopen.74732

Costa, E., Santos, L. C. R., \& Vieira, L. C. R. (2011). Produção de mudas de mamoeiro utilizando diferentes substratos, ambientes de cultivo e recipientes. Engenharia Agrícola, 29(4), 528-537. https://doi.org/ $10.1590 / \mathrm{S} 0100-69162009000400003$

Dat, J., Vandenabeele, S., Vranov, E., Van Montagu, M., Inz, D., \& Van Breusegem, F. (2000).Dual action of the active oxygen species during plant stress responses. Cellular and Molecular Life Sciences, 57(5), 779-795. https://doi.org/10.1007/s000180050041

EMBRAPA (Empresa Brasileira de Pesquisa Agropecuária). (2013). Sistema brasileiro de classificação de solos. Centro Nacional de Pesquisa de solos (p. 353). Rio de Janeiro.

FAOSTAT (FAO Statistics Database). (2018). Retrieved from http://www.fao.org/faostat/en/\#data/QC

Ferrante, A., \& Mariani, L. (2018). Agronomic Management for Enhancing Plant Tolerance to Abiotic Stresses: High and Low Values of Temperature, Light Intensity, and Relative Humidity. Horticulturae, 4(3), 21. https://doi.org/10.3390/horticulturae4030021

Figueiredo, E. B., Malheiros, E. B., \& Braz, L. T. (2002). Avaliação de cultivares de alface em túnel baixo de cultivo forçado, na região de Jaboticabal-SP. Horticultura Brasileira, 20(2), 20-24.

Geiger, R. (1980). Manual de micrometeorologia (p. 556). Lisboa: Calouste Gulbenkian.

Li, J. C. (2016). Uso de mallas em invernaderos. Horticultura Internacional, 86-91. Retrieved from http://www.horticom.com/revistasonline/revistas/viveros06/jc_li.pdf

Maynard, D. N., \& Hochmuth, G. J. (2007). Knott's handbook for vegetable growers (5th ed.). John Wiley \& Sons. Inc. https://doi.org/10.1002/9780470121474 
Nogueira, S. F., Grego, C. R., Quartaroli, C.F., Andrade, R.G., Holler, W. A., \& Vital, D.M. (2011). Estimativa de estoque de carbono em sistemas de produção de soja na região norte Mato-Grossense.

Oliveira, S. K. L., Grangeiro, M. Z., Souza, B. S., \& Souza, S. R. R. (2006). Cultivo de alface com proteção de agrotêxtil em condições em altas temperaturas e luminosidade. Caatinga, 19(2) 112-116.

Pezzopane, J. E. M., Oliveira, P. C. de, Reis, E. F. dos, \& Lima, J. S. de S. (2004). Alterações microclimáticas causadas pelo uso de tela plástica. Engenharia Agrícola, 24(1), 9-15. https://doi.org/10.1590/ S0100-69162004000100002

Pires, M. M. M. L., Santos, H. A., Santos, D. F., Vasconcelos, A. S., \& Aragão, C. A. (2013). Produção do meloeiro submetido a diferentes manejos de água com o uso de manta de tecido não tecido. Horticultura Brasileira, 31, 304-310. https://doi.org/10.1590/S0102-05362013000200021

Rampazzo, R., Seabra Júnior, S., Nunes, M. C. M., \& Neves, S. M. A. S. (2014). Eficiência de telas termorrefletoras e de sombreamento em ambiente protegido tipo telado sob temperaturas elevadas. Engenharia na agricultura, 22(1), 33-42. https://doi.org/10.13083/1414-3984.v22n01a04

Rodriguez, V. M., Soengas, P., Alonso-Villaverde, V., Sotelo, T., Cartea, M. E., \& Velasco, P. (2015). Effect of temperature stress on the early vegetative development of Brassica oleracea L. BMC Plant Biology, 15(1), 1-9. https://doi.org/10.1186/s12870-015-0535-0

Romanini, C. E. B., Garcia, A. P., Alvarado, L. M., Cappelli, N. L., \& Umezu, C. (2010). Desenvolvimento e simulação de um sistema avançado de controle ambiental em cultivo protegido. Revista Brasileira de Engenharia Agrícola e Ambiental, 14(11), 1193-1201. https://doi.org/10.1590/S1415-43662010001100009

Sales, F. A. L., Barbosa Filho, J. A. D., Barbosa, J. P. A. D., Viana, T. V. A., \& Freitas, C. A. S. (2014). Telas agrícolas como subcobertura no cultivo de alface hidropônica. Ciência Rural, 44(10), 1755-1760. https://doi.org/10.1590/0103-8478cr20120633

Silva, F. A. S., \& Azevedo, C. A. V. (2016).The Assistat Software Version 7.7 and its use in the analysis of Experimental data. African Journal Agriculture Research, 11(39), 3733-3740. https://doi.org/10.5897/ AJAR2016.11522

Szabados, L., Kováscs, H., Zilberstein, A., \& Bouchereau, A. (2011). Plants in extreme environments: Importance of protective compounds in stress tolerance. Advances in Botanical Research, 5, 106-133. https://doi.org/10.1016/B978-0-12-387692-8.00004-7

Trani, P. E., \& Raij, B. V. (1996). Hortaliças. Recomendações de adubação e calagem para o estado de São Paulo (2nd ed., pp. 157-186). Campinas: IAC.

Wise, R. R., Olson, A. J., Schrader, S. M., \& Sharkey, T. D. (2004). Electron transport is the functional limitation of photosynthesis in field-grown Pima cotton plants at high temperature. Plant, Cell and Environment, 27(6), 717-724. https://doi.org/10.1111/j.1365-3040.2004.01171

\section{Copyrights}

Copyright for this article is retained by the author(s), with first publication rights granted to the journal.

This is an open-access article distributed under the terms and conditions of the Creative Commons Attribution license (http://creativecommons.org/licenses/by/4.0/). 